\title{
Direct Evidence of Egestion and Salivation of Xylella fastidiosa Suggests Sharpshooters Can Be "Flying Syringes"
}

\author{
Elaine A. Backus, Holly J. Shugart, Elizabeth E. Rogers, J. Kent Morgan, and Robert Shatters
}

First and third authors: U.S. Department of Agriculture (USDA)-Agricultural Research Service (ARS), San Joaquin Valley Agricultural Sciences Center, 9611 S. Riverbend Ave., Parlier, CA 93648-9757; second author: University of Florida, Department of Entomology, Citrus Research and Education Center, 700 Experiment Station Rd., Lake Alfred, FL 33850; and fourth and fifth authors: USDA-ARS, U.S. Horticultural Research Lab., Subtropical Insects and Horticulture Research, 2001 S. Rock Rd., Ft. Pierce, FL 34945.

Accepted for publication 23 December 2014.

\begin{abstract}
Backus, E. A., Shugart, H. J., Rogers, E. E., Morgan, J. K., and Shatters, R. 2015. Direct evidence of egestion and salivation of Xylella fastidiosa suggests sharpshooters can be "flying syringes". Phytopathology 105:608-620.

Xylella fastidiosa is unique among insect-transmitted plant pathogens because it is propagative but noncirculative, adhering to and multiplying on the cuticular lining of the anterior foregut. Any inoculation mechanism for $X$. fastidiosa must explain how bacterial cells exit the vector's stylets via the food canal and directly enter the plant. A combined egestion-salivation mechanism has been proposed to explain these unique features. Egestion is the putative outward flow of fluid from the foregut via hypothesized bidirectional pumping of the cibarium. The present study traced green fluorescent protein-expressing $X$. fastidiosa or fluorescent nanoparticles

saliva. X. fastidiosa or nanoparticles were shown to mix with gelling saliva to form fluorescent deposits and salivary sheaths on artificial diets, providing the first direct, conclusive evidence of egestion by any hemipteran insect. Therefore, the present results strongly support an egestionsalivation mechanism of $X$. fastidiosa inoculation. Results also support that a column of fluid is transiently held in the foregut without being swallowed. Evidence also supports (but does not definitively prove) that bacteria were suspended in the column of fluid during the vector's transit from diet to diet, and were egested with the held fluid. Thus, we hypothesize that sharpshooters could be true "flying syringes," especially when inoculation occurs very soon after uptake of bacteria, suggesting the new paradigm of a nonpersistent $X$. fastidiosa transmission mechanism.
\end{abstract} acquired from artificial diets by glassy-winged sharpshooters, Homalodisca vitripennis, as they were egested into simultaneously secreted

Science has enduring mysteries whose solutions usually require the development of new technology over time. One such mystery has been the inoculation mechanism of a unique, insect-transmitted, bacterial plant pathogen, Xylella fastidiosa (Wells et al.), despite nearly 70 years of research (5). X. fastidiosa colonizes only two places (14): xylem cells and the anterior-most regions of the functional foregut, chiefly the oral cavity comprised of the precibarium and cibarium (or antecibarium and postcibarium, respectively [sensu Harris and Harris (26)]), in its xylem-ingesting hemipteran vectors, principally sharpshooter leafhoppers (Auchenorrhyncha: Cicadellidae: Cicadellinae).

Using a noncirculative mechanism of transmission (i.e., acquisition, retention, and inoculation), $X$. fastidiosa bacteria are thought to be taken up into the foregut during xylem sap ingestion, and then to rapidly begin a multistep attachment process initially mediated by hemagglutin-like adhesion proteins (30), but ultimately culminating in establishment of dense, multiplying, biofilm colonies (9) tightly adhering to the cuticle via an exopolysaccharide (EPS) matrix (50). Thus, $X$. fastidiosa is unusual among insect-transmitted plant pathogens in being noncirculative $(47)$, foregut-borne $(2,48)$ but propagative in its vectors (27). Semipersistent during nymphal instars of the vector, attached bacteria are sloughed off with the

Corresponding author: E. A. Backus; E-mail address: Elaine.Backus@ars.usda.gov

*The $\boldsymbol{e}$-Xtra logo stands for "electronic extra" and indicates that one supplementary file is published online.

http://dx.doi.org/10.1094/PHYTO-09-14-0258-R

This article is in the public domain and not copyrightable. It may be freely reprinted with customary crediting of the source. The American Phytopathological Society, 2015 .
Additional keywords: acquisition, Pierce's disease. cuticle during molting; $X$. fastidiosa must be reacquired during the next nymphal stadium. After the vector has eclosed to adulthood and no longer molts, the bacteria (once acquired) become persistent (1,27). Attached bacterial cells are then somehow directly inoculated from the foregut into newly probed xylem cells in a healthy plant.

Two of the most recalcitrant questions about the $X$. fastidiosa inoculation mechanism have been (i) how are the bacteria, once inside the foregut, conveyed back out the stylet tips during stylet probing/penetration, and (ii) why is there sometimes (essentially) no latent period ( $<60 \mathrm{~min}$ in laboratory experiments) (47) between acquisition and inoculation? This study provides evidence to answer both of these questions.

Recently, Backus et al. $(5,7,9)$ proposed that $X$. fastidiosa inoculation occurs through a combination of salivation and egestion. Egestion is hypothesized (but not conclusively proven) to be a process by which all hemipterans can expel fluid outward from the functional foregut through the opening of the food canal in the stylet tips $(8,9,25)$. In the case of $X$. fastidiosa, the precibarium is thought to be the likely "staging area" in the functional foregut from which bacteria are egested $(2,8,9,27)$.

The concept of egestion and whether it occurs in hemipteran feeding has had a storied history in vector biology, with applications far beyond $X$. fastidiosa and much controversy over the last 40 years (56). Results of the present study put the controversy to rest because they conclusively prove that egestion exists. However, to best appreciate the solution to the controversy, one should understand the nature of the challenge and evidence that accumulated over the years.

The egestion concept was introduced during the more than 80-year search for a mechanism for inoculation of nonpersistent/ noncirculative ("stylet-borne") plant viruses by aphids. In the 1940s 
through 1970s, numerous experiments were performed (reviewed by Watson and Plumb [56]) to elucidate how such viruses could be rapidly acquired from epidermal cells within seconds of the start of aphid probing, then inoculated within minutes, in a nearly nonspecific manner. Some researchers argued that transmission was strictly mechanical, with viruses adsorbing to outer or inner surfaces of the maxillary stylets then being dropped or scrubbed off. Thus, aphids (like some mosquitoes [19]) were "flying pins" (17). The research of Bradley (11) and Bradley and Ganong (12,13) supported this hypothesis by showing that formaldehyde or radiation treatments of the stylet tips prevented inoculation of previously acquired virus. Other researchers proposed that viruses were held, suspended, in a fluid column in the foregut and liberated by fluid being pushed outward. This model suggested that aphids were "flying syringes" (10), even though the mechanism of outward fluid flow was unknown. The flying syringe model for nonpersistent virus inoculation depended upon three linked, but unproven, ideas: (i) unbound viruses suspended in fluid being taken up into the foregut, (ii) the fluid being held in the foregut without being swallowed, and (iii) the fluid (with suspended viruses) being egested back out of the foregut and stylet tips. Because the mechanism of fluid flow was unknown, the linchpin of the model was the existence of egestion.

Watson and Plumb (56) suggested that outward fluid flow may occur via regurgitation from the midgut. The first evidence for this idea was published by Harris and Bath (25), who observed carbon particles pushed outward from aphid stylet tips by expelled liquid, when aphids were feeding in transparent artificial diet chambers. However, this explanation was countered by Watson and Plumb's later observations (56) that hemipterans have a highly developed esophageal valve (dividing the esophagus, the posterior-most part of the foregut, from the midgut). Ingested (i.e., swallowed) fluid that has passed through this one-way valve cannot return to the foregut (22). Harris and Bath (25) then made the first adjustment of his concept, proposing that outward fluid flow is from only the anterior (functional) foregut (anatomy more thoroughly explained in Backus [5]), and named the process egestion to distinguish it from regurgitation (24). He also proposed the ingestion-egestion hypothesis for acquisition and inoculation, respectively, of nonpersistent viruses $(24,26)$. In support of this hypothesis, Kloft (32) found that if aphids were fed on tritium-labeled plants for hours to days and then transferred to leaf discs for access times of 0.5 to $15 \mathrm{~min}$, they sometimes injected copious tritium into the leaf discs. However, both Harris and Bath (25) and Kloft (32) have been criticized (18) because neither could differentiate between egestate and saliva exiting the stylets. Radiolabels can be quickly mobilized from the gut into the hemolymph, of which watery saliva is a filtrate (38). Kloft (32) also showed that $\mathrm{P}^{32}$ ingested from radiolabeled plants is secreted in saliva only $5 \mathrm{~h}$ after the start of access time.

By the 1960s to 1980s, electropenetrographic monitoring of insect feeding $(37,51)$ was being used to investigate aphid transmission of nonpersistent viruses. The discovery of intracellular punctures into epidermal and mesophyll cells along the stylet pathway to phloem (52), and that salivation during these punctures was associated with nonpersistent virus inoculation $(45,46)$, gave rise to the ingestionsalivation hypothesis $(18,36)$, as a counter to the ingestion-egestion hypothesis. In response to the idea that salivation is the vehicle for virus inoculation, Harris and Harris (26) again modified his hypothesis to suggest that watery saliva could be taken up into the functional foregut, mixed with liquid food, then egested outward.

The eventual finding of helper compounds suggested that nonpersistent viruses bind to specific sites in or on the stylets or foregut of aphids, not just mechanically adsorbed to the stylet cuticle (56). Thus, a more biological component (receptor-based virus adherence to cuticle) was added to the purely mechanical mechanism in the flying pin model. The most important recent achievement for understanding nonpersistent virus inoculation by aphids came when Uzest and colleagues (54) discovered a patch of cuticle at the tip of the stylets, the "acrostyle," inside the common canal where the food and salivary canals conjoin in aphids. Virus particles bind to the acrostyle, from which they are presumably inoculated into the plant (55). No binding of nonpersistent viruses has been found anywhere else along the functional foregut of aphids. Because the food and salivary canals conjoin in aphids (and in absence of evidence for egestion), ejection of viruses from the acrostyle is presently thought to occur via watery salivation (18), not egestion. Uzest's findings $(54,55)$ that aphid-transmitted viruses really could be "stylet-borne" vindicated the decades-old work of Bradley (11) and Bradley and Ganong (12,13), supporting a narrow biological version of the 'flying pin' model. Thus, egestion (of fluid from the functional foregut above the stylet tips) as a concept in its original context, i.e., aphid inoculation of nonpersistent viruses, is considered a discredited hypothesis $(18,54)$.

Yet, aphids are not the only vectors that transmit pathogens (once or still) thought to be foregut-borne (42). A few leafhopper species are vectors of semipersistent pathogens, such as the xylem-limited $X$. fastidiosa transmitted by sharpshooters, and the phloem-limited Maize chlorotic dwarf virus (MCDV) transmitted by Graminella nigrifrons (Forbes). MCDV particles have been found to bind to the foregut cuticle in G. nigrifrons (43). When definitive evidence shows that a noncirculative pathogen adheres to the foregut proximal to the stylet tips, as with MCDV and X. fastidiosa (9), the concept of egestion as a conveyor of pathogens outward cannot be dismissed. Indeed, it is the only logical possibility, notwithstanding one that has been very difficult to prove conclusively.

The objectives of this study were to follow the processes of acquisition and inoculation of X. fastidiosa, into and out of the stylets. We studied one of most the economically important vectors, the glassy-winged sharpshooter, Homalodisca vitripennis (Takiya), in order to answer the above two, recalcitrant questions, i.e., how do bacteria come out of the stylets, and why can there sometimes be no latent period between acquisition and inoculation?

Our results provide the first conclusive proof of the existence of egestion by any hemipteran insect. They also strongly support that a column of fluid can be held in the functional foregut without being swallowed, before it is expelled back out of the stylets. Our findings could not definitively determine whether $X$. fastidios a cells ejected from stylets had been suspended in held-fluid or had briefly adhered to cuticle and then were loosened, prior to egestion. However, during short time periods after fluid uptake and before bacterial adherence, suspension is distinctly possible. Therefore, we hypothesize that sharpshooters can, at times, act as true flying syringes (10) in the inoculation of $X$. fastidiosa, by carrying a fluid column with suspended bacteria between food sources. Rapid egestion of the bacteria-laden fluid could explain the absence (in some circumstances) of a latent period for X. fastidiosa.

\section{MATERIALS AND METHODS}

For extensive details of methods, including rearing insects to be $X$. fastidiosa-free, construction of artificial diet chambers, observations of sharpshooter feeding on diet, quantitative polymerase chain reaction (qPCR), confocal microscopy, immunostaining, as well as color separation methods and further results (Supplementary file).

$X$. fastidiosa culture. $X$. fastidiosa, Temecula strain, transformed to express green fluorescent protein (hereafter, $X$. fastidiosa GFP) (44) were maintained at $28^{\circ} \mathrm{C}$ on standard periwinkle wilt (PW) medium (16) modified with Gel-Rite for solidification (PWG), as previously described (15). Bacteria used for experiments were streaked onto plates of XFM-Pectin, per the methods in Killiny and Almeida (29), grown until the colonies expressed the "sticky" mucous-like phenotype (with over-production of EPS [30,31] for improved adhesion to cuticle), and then used for acquisition in artificial diets.

Insect and plant rearing. For experiments 1 to 3 , insects were reared on sunflower, Helianthus annus L., cowpea, Vigna unguiculata (L.) Walp., okra, Abelmoschus esculentus (L.) Moench, basil, Oncimum basilicum L., and sorghum, Sorghum bicolor L., plants (all 
in same cage) from field-collected or colony-reared eggs. Colonies were reared under artificial lighting (mixed sodium-vapor and LED lamps; $14 \mathrm{~h}$ light/10 $\mathrm{h}$ dark) in a quarantine insectary at the USDAARS San Joaquin Valley Agricultural Sciences Center in Parlier, CA. In order to assure that insects used in experiments were $X$. fastidiosafree prior to acquisition of $X$. fastidiosa GFP in vitro (see $X$. fastidiosa acquisition diet, below), host plants for nymphal rearing were changed weekly.

For experiment 4, glassy-winged sharpshooters were reared on a combination of okra, basil, and euonymus, Euonymus japonica Thunb. plants (all in the same cage) in a greenhouse maintained at $24^{\circ} \mathrm{C}$ with a combination of natural and artificial lighting (16 h light/8 h dark) at the U.S. Horticulture Research Laboratory (USDA-ARS) in Ft. Pierce, FL.

Designs of experiments 1 to 3 . Three experiments and two controls were performed, with the entire set of experiments and controls replicated twice. As diagrammed in Table 1, the project was designed as a stepwise, sequential progression of controls and experiments, so that each step repeated and built upon the protocols performed in the previous one. Our intent was to trace the progress and location of $X$. fastidiosa bacterial cells (going into or coming out of the insect) through each major step in the sharpshooter feeding process, pausing after each step to destructively sample for $X$. fastidiosa using a variety of methods to ensure the highest likelihood of bacterial detection. Thus, we separately searched for $X$. fastidiosa after each of the following states/steps (Table 1): (step 1) pre-acquisition controls: initial conditions of insects in the colony, (step 2) post-acquisition controls: after colony insects were given a 24-h acquisition access period (AAP) on "acquisition" artificial diet containing $X$. fastidiosa GFP, (step 3) experiment 1: after these $X$. fastidiosa diet-fed insects were allowed to clear their guts via a few observed probes for less than 60 min on a plain " $1 \mathrm{st}$ clearing diet" (i.e., not containing X. fastidiosa), (step 4) experiment 2: after foregut-cleared insects were allowed access to a different, plain " 2 nd clearing diet" for one to three observed probes during no more than $4 \mathrm{~h}$ observation time, and (step 5) experiment 3 : after the 1 st clearing diet, insects were given a 24-h multiplication period (MP) on a cowpea plant followed by another, plain "post-cowpea diet." Research questions asked at each step of this feeding progression are included in Table 1.

Each control repetition had a sample size of 9 to 12 insects, for a total of 40 insects sampled; each experiment had a sample size of eight and was repeated twice, resulting in a total of 48 experimental insects that started the three experiments. However, five insects died during the course of these experiments, resulting in a final experimental sample size of 43 insects.

$X$. fastidiosa acquisition diet. Approximately $5 \mathrm{ml}$ of artificial diet (28) containing $X$. fastidiosa GFP (concentration $10^{8} \mathrm{cfu} / \mathrm{ml}$ )

TABLE 1. Experimental design for controls and experiments reported herein ${ }^{z}$

\begin{tabular}{|c|c|c|c|c|c|c|}
\hline Step & $\begin{array}{l}\text { Pre-acquisition } \\
\text { controls }\end{array}$ & $\begin{array}{l}\text { Post-acquisition } \\
\text { controls }\end{array}$ & Experiment 1 & Experiment 2 & Experiment 3 & $\begin{array}{c}\text { Summary of analyses } \\
\text { performed }\end{array}$ \\
\hline 1 & & $\begin{array}{l}X . \text { fastidiosa GFP diet } \\
(24 \text { h AAP })\end{array}$ & $\begin{array}{l}\text { X. fastidiosa GFP diet } \\
(24 \mathrm{~h} \mathrm{AAP})\end{array}$ & $\begin{array}{l}\text { X. fastidiosa GFP diet } \\
(24 \mathrm{~h} \mathrm{AAP})\end{array}$ & $\begin{array}{l}\text { X. fastidiosa GFP diet } \\
(24 \mathrm{~h} \mathrm{AAP})\end{array}$ & \\
\hline \multirow[t]{2}{*}{2} & $\begin{array}{l}\text { 1. Were } X \text {. fastidiosa or } \\
\text { other microbes } \\
\text { present before } \\
\text { acquisition? }\end{array}$ & $\begin{array}{l}\text { 2. Did } X \text {. fastidiosa } \\
\text { GFP bacteria } \\
\text { adhere to and } \\
\text { colonize foregut } \\
\text { cuticle after } 24 \mathrm{~h} \\
\text { AAP? }\end{array}$ & $\begin{array}{l}\text { 1st clearing diet } \\
(<60 \mathrm{~min})\end{array}$ & $\begin{array}{l}\text { 1st clearing diet } \\
(<60 \mathrm{~min})\end{array}$ & $\begin{array}{l}\text { 1st clearing diet } \\
(<60 \text { min })\end{array}$ & \\
\hline & $\begin{array}{l}\text { 1. Answer: No } \\
X . \text { fastidiosa, but } \\
\text { other microbes were } \\
\text { present throughout } \\
\text { the foregut. }\end{array}$ & $\begin{array}{l}\text { 2. Answer: No, or very } \\
\text { little. }\end{array}$ & $\begin{array}{l}n=13 \text { (PCR heads) } \\
n=13 \text { (culture diets) } \\
n=3 \text { (probing data and } \\
\text { confocal films from } \\
\text { insects } 1 \text { through } 3 \text { ) }\end{array}$ & $\begin{array}{l}n=15 \text { (culture diets) } \\
n=5 \text { (probing data and } \\
\text { confocal films from } \\
\text { insects } 4 \text { through } 7)\end{array}$ & $\begin{array}{l}n=16 \text { (culture diets) } \\
n=3 \text { (probing data) }\end{array}$ & $\begin{array}{l}n=13 \text { (PCR heads) } \\
n=44 \text { (culture diets) } \\
n=8 \text { (confocal films) }\end{array}$ \\
\hline 4 & & & $\begin{array}{l}\text { 4. Were } X \text {. fastidiosa } \\
\text { GFP bacteria } \\
\text { ejected after } \\
\text { transfer to a second } \\
\text { diet chamber? }\end{array}$ & $\begin{array}{l}\text { 4. Answer: Yes, half } \\
\text { the dab area was } \\
\text { bacterial, half } \\
\text { saliva; thus, more } \\
\text { gelling saliva was } \\
\text { ejected. }\end{array}$ & $\begin{array}{l}\text { Cowpea plant }(24 \mathrm{~h}) \\
n=16 \text { (PCR plants) }\end{array}$ & $n=16$ (PCR plants) \\
\hline
\end{tabular}

\footnotetext{
${ }^{\mathrm{z}}$ Numbered Steps within each column explain the sequential protocols performed for each control or experiment (column). Bolded questions are in relation to the Step number bolded, even if space limitations required they be placed in rows different from that of their numbered Step. Summary of analyses (final column) is for each Step. Films, parafilm covers of artificial diet feeding sachets; and $n$, sample size of insects for each analysis method listed.
} 
(hereafter termed $X$. fastidiosa GFP diet) was parafilm-sealed into the 1-mm deep lid of a Lab-Tek Nunc (Fisher Scientific) single-unit chamber-slide apparatus, similar to that pictured in Habibi et al. (23). Diet chambers were kept under artificial light for a full 24-h AAP, during which insects were not directly observed for feeding. Previous studies have shown that any sharpshooters surviving $24 \mathrm{~h}$ on diet must probe and ingest diet (E. A. Backus, unpublished data).

Observations of insects in diet chambers. Stylets were viewed under a binocular stereoscan microscope (Leica MZ12.5, JH Technologies, San Jose, CA), allowing the observer to count and time the number and durations of all ingestion-containing stylet probes, respectively. However, because some insects rapidly began labial dabbing and test probing immediately upon placement in a chamber, and eight insects had to be observed at once, some early probes were not observed. When an insect was observed probing, a circle was drawn on the back of the glass slide to indicate the location of each probe, so that any salivary deposits left on the corresponding area of the parafilm could be located for subsequent analysis. During Rep 2 observations only, a number indicating the performance order of each probe was also drawn on the slide near each circle.

Controls and experiment 1. Half of the control insects were tested for $X$. fastidiosa via qPCR (see Analysis methods: qPCR, below); the other half via confocal laser scanning microscopy (CLSM) (see Analysis methods, CLSM below). After the postacquisition observation period for experiment 1 (Table 1), all chamber slides housing 1st clearing diets were disassembled and insects removed. Pieces of parafilm diet covers were examined with the same Leica MZ12.5, and those containing deposits (corresponding to the circles on the slide) were cut out, placed in $4 \%$ paraformaldehyde, and stored for later processing and CLSM examination. Remaining diet volumes from each insect-fed chamber were individually collected (using sterile technique in a biosafety cabinet) into a vial, pelleted, and cultured on XFM+pectin diet (see Analysis methods: $X$. fastidiosa culturing, below). Finally, each insect was individually numbered and frozen, and its dissected head was assayed via qPCR.

Experiment 2. The same steps as in experiment 1 were repeated. However, after disassembly of the chamber slides housing 1st clearing diets, insects were immediately transferred to new chamber slides with fresh, plain diet (2nd clearing diets) (Table 1). Insect probing was observed as described for experiment 1 for no more than $4 \mathrm{~h}$, until all insects in a tray had performed at least one probe. Following this observation period, chamber slides were again disassembled, and parafilm covers, diets and insects were processed in the same manner as for experiment 1 .

Experiment 3. The same steps as in experiment 1 were repeated. However for this experiment, after their removal from the 1st clearing diets, insects were pooled for each repetition and then immediately tube-caged on a single, small $(15$ to $20 \mathrm{~cm}$ ) cowpea plant (3 weeks old, grown under same conditions as insect rearing plants [see Insects and plants, above]) for a 24-h bacterial MP. Diet fluids from the 1st clearing diet chambers were processed for culturing (see Analysis methods, $X$. fastidiosa culturing, below). After the MP was completed, insects were removed from the cowpea plant and transferred to a new chamber with fresh, plain diet and otherwise identical to the 1 st and 2nd clearing diets, as a post-cowpea diet (Table 1). Sharpshooter stylet probing was again observed under a stereoscan microscope for 30 to $60 \mathrm{~min}$, whereupon chamber slides were again disassembled, and parafilm covers, diet, and insects were processed the same as for experiments 1 and 2 .

Analysis methods. X. fastidiosa culturing. After disassembly of chamber slides, diets were individually centrifuged at $2,000 \times g$ ( $2 \mathrm{~min}$ ), and a $20-\mu \mathrm{l}$ subsample of fluid plus precipitate from the pellet was streaked onto XFM+pectin media and incubated for 2 months at $28^{\circ} \mathrm{C}$, as previously described (28). Plates were examined visually once per week and microscopically once every 2 weeks for $X$. fastidiosa growth. A total of 71 diet samples was cultured (Table 1).
CLSM. Insect heads (from 22 control insects) and cut pieces of parafilm diet covers (from 43 diets) were fixed in $4 \%$ paraformaldehyde. All insect heads and selected pieces of parafilm were then mounted in glycerin (without washing, to prevent bacteria from being washed away) and examined via CLSM (Leica SP2 AOBS, JH Technologies, San Jose, CA). Locations of salivary deposits were mapped for future reference. $X$. fastidiosa GFP was visualized using the $476 \mathrm{~nm}$ laser with detection windows set to 492 to $528 \mathrm{~nm}$, false-colored green. Gelling saliva (on diet parafilms) or wild-type bacteria (in insect heads) were visualized using the 633 laser with detection windows set to 528 to $610 \mathrm{~nm}$, false-colored red. Colocalized red and green (overlay, thus $X$. fastidiosa GFP embedded in gelling saliva) were digitally blended to create yellow tones. Each image captured one to multiple surface deposits or salivary sheaths.

Due to the extremely time-consuming process of CLSM, only covers from seven 1st clearing diet parafilms were examined and imaged. Additionally, only parafilm pieces from five 2 nd clearing diets and four post-cowpea diets were ultimately imaged, due to difficulty in locating salivary deposits (especially on post-cowpea diet parafilms). Therefore, remaining examination of parafilm pieces was terminated.

Image color separation and statistical analysis. All CLSM images of two-dimensional surface deposits (dabs) were quantitatively analyzed via Image-Pro Plus v. 7.0 software (MediaCybernetics, Rockville, MD). Most individual images had more than one dab. Data were compiled in Excel, then statistically tested for significant differences both among treatments and within treatments, using the REML adjustment for mixed-model ANOVA (Proc Glimmix) in SAS (Cary, NC). For tests within experiment, data from all insects were used. However, because insect number 7 was the only sharpshooter whose surface deposits were quantified from two, sequential experiments ( $1 \mathrm{st}$ and 2 nd clearing diets), data from insect 7 on the 2 nd clearing diet were deleted for tests among experiments, to avoid autocorrelation. Area measurements were log-transformed prior to analysis, to reduce heterogeneity. Results were considered significantly different at $\alpha=0.05$.

Immunostaining of parafilm diet covers. To independently verify that green fluorescent deposits on parafilm actually indicated $X$. fastidiosa GFP, parafilm covers from four clearing diets from experiment 1 , Rep 1 (i.e., from insects 3, 4, 5, and 6), were placed on microscope slides with silicon gaskets to float freely in fluids for immunocytochemical processing and detection of $X$. fastidiosa. Methods were previously described in detail (6). Slides were examined via CLSM, as above.

$q P C R$. Insects were frozen at $-20^{\circ} \mathrm{C}$ immediately after treatment. Frozen insects were dissected so that only the cibarium, precibarium and stylets (with a small amount of surrounding tissues) remained for DNA extraction and analysis via qPCR, thus minimizing potential for inhibition by insect-derived chitin. DNA was extracted as previously described (21), with minor modifications. Cowpea (MP) plants from experiment 3 were held in a greenhouse for 14 days after exposure to insects, to allow for $X$. fastidiosa growth. Leaf and stem tissues were then excised and frozen at $-20^{\circ} \mathrm{C}$ until DNA extraction was performed. For both insect and cowpea DNA extracts, qPCR was performed as previously described (34) using Xf145-60F and Xf145-60R primers in a StepOne Plus qPCR machine (Applied Biosystems, Foster City, California). Primers GFP F452 (5'-CATCATGGCAGACAAA CAAAAGA-3') and GFP R601 (5'-AGGTAATGGTTGTCTGG TAAAAGGA-3') were used to specifically detect $X$. fastidiosa GFP. A total of 63 sharpshooter heads and 16 cowpea plants were analyzed by qPCR (Table 1 ).

Design and methods of experiment 4. Colony-reared sharpshooters were collected in polystyrene containers and allowed to remain for $4 \mathrm{~h}$ at $23^{\circ} \mathrm{C}$ to induce hunger. Following this starvation period, insects were placed individually into $35 \mathrm{~mm} \times 10 \mathrm{~mm}$ plastic petri dishes and a single layer of Parafilm was stretched across the top to seal the plate. To this, $175 \mu$ of a 50:50 mix of Fluorophorex 
Green Fluorescent Polystyrene Nanoparticles (0.05 $\mu \mathrm{m}$ diameter) (Catalog Number 2101, Phosphororex, Inc., Hopkinton, MA) and water was added, and then covered with a single layer of clear 'kitchen' style plastic wrap, creating a parafilm-nanoparticleplastic wrap sandwich.

Insects were observed and verified to stylet probe across the parafilm membrane into the fluorescent bead solution. No more than 30 min was required to observe that all insects had begun to stylet-probe the nanoparticle-laden diet. Subsequent to probing the diet, insects were then immediately transferred to new $35 \mathrm{~mm} \times$ $10 \mathrm{~mm}$ plastic petri dishes and a single layer of Parafilm was stretched across the top, creating an air-filled 'mock' feeding chamber (MFC) (41). GWSS were then observed to probe across the single parafilm layer, and salivary sheaths formed in air were observed by inverting the MFC on an Olympus IX70 (Olympus, Tokyo, Japan) inverted fluorescence microscope as has been previously described (41).

Micrographs were captured using an Olympus DP73 camera system (Olympus) using either bright field or green via a wide UV excitation U-MWU filter cube (Olympus) (the latter to visualize the green fluorescence of the nanoparticles with the least amount of bleed-through of autofluorescence from the salivary sheath), coupled with cellSens Dimension version 1.6 (build 9457) imaging software (Olympus). Control experiments were performed in parallel as described, with water substituted in place of the fluorescent nanoparticle solution.

\section{RESULTS}

General findings for controls. Pre-acquisition control insects (taken straight from colony rearing cages) were all negative for detection of $X$. fastidiosa, either by qPCR (no $X$. fastidiosa detected above the limit of ca. 50 bacterial cells) or by CLSM. However, varying amounts of unknown, wild-type (non-GFP) microbes were seen in all parts of the functional foregut and stylet food canal (data not shown, but similar to micrographs in Figure 1, microbes falsecolored bright red). Similarly, post-acquisition control insects, sampled immediately after the $24 \mathrm{~h}$ AAP on $X$. fastidiosa
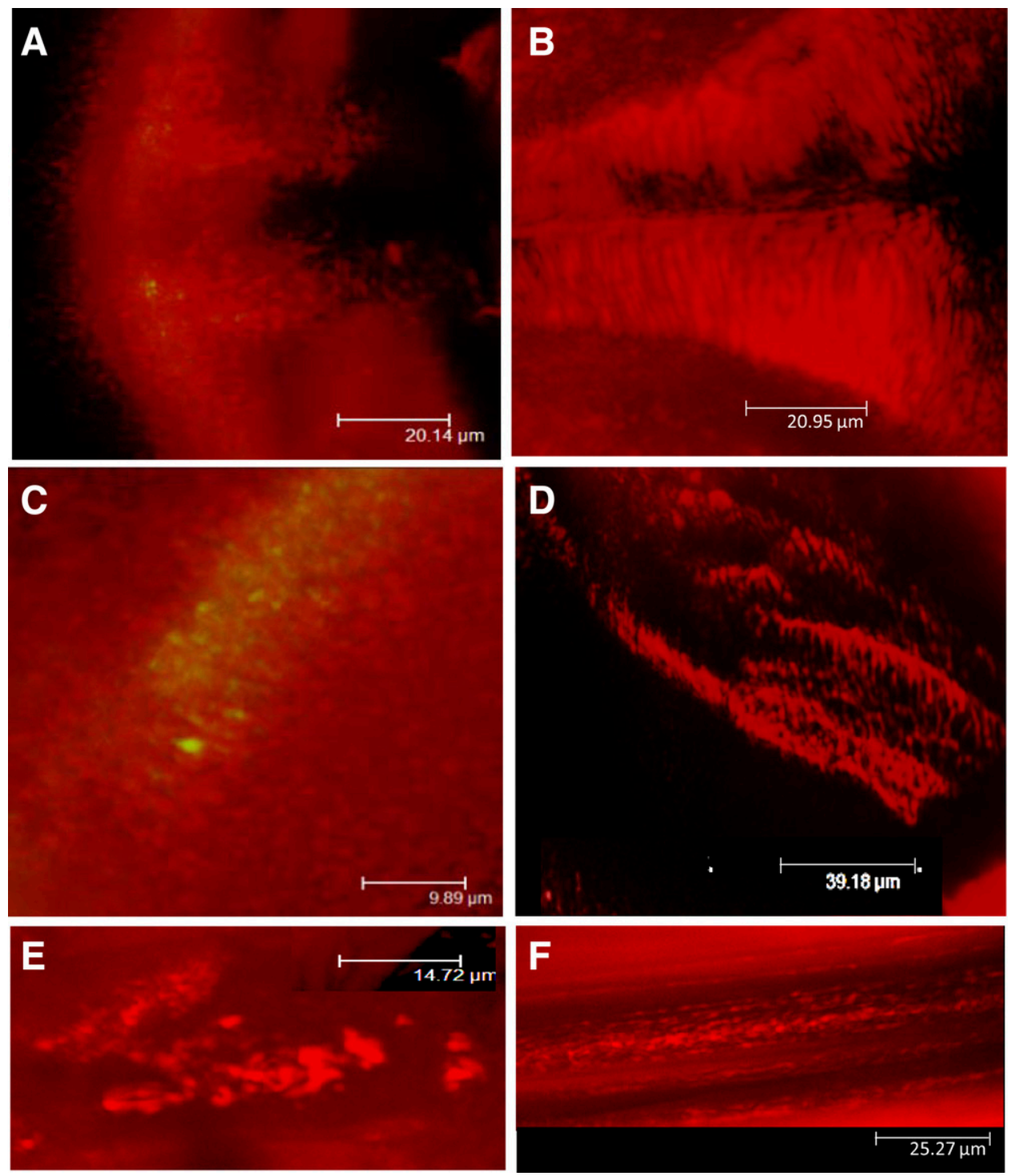

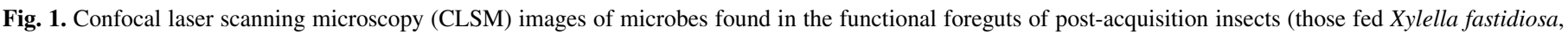

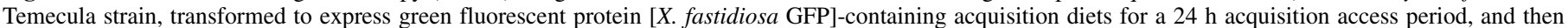

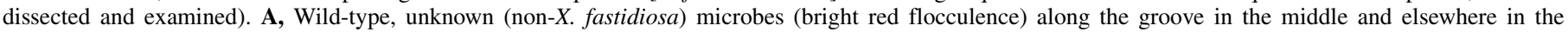

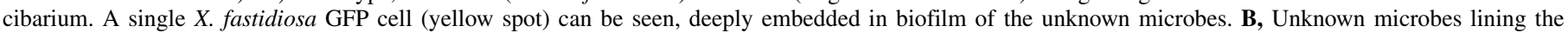

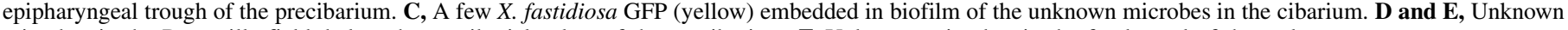
microbes in the D-sensilla field, below the precibarial valve, of the precibarium. F, Unknown microbes in the food canal of the stylets. 
GFP-containing diet, were all negative by qPCR, for either or $X$. fastidiosa GFP. Variable amounts (often large) of unknown microbes again were found via CLSM in oral cavity, i.e., the cibarium (Fig. 1A, B, and C) and precibarium (Fig. 1D and E), as well as the stylet food canal (Fig. 1F). Only single cells (Fig. 1A) or tiny patches (Fig. 1C) of $X$. fastidiosa GFP were present, as indicated by yellow or green fluorescence. $X$. fastidios $a$ GFP were usually embedded in the microbial biofilm of unknown microbes (as indicated by the yellow overlay color in Figure 1A and C; green indicates $X$. fastidiosa GFP alone).

General findings for experiments 1 to 3 . Results presented are for all bacterial detection methods from all 40 insects in all three experiments, except in the case of probing data and CLSM imaging of parafilm diet covers. Probing data are presented for only the 14 insects whose salivary deposits were later imaged with CLSM. Probing of those 14 insects was highly representative of the remaining 26 insects, who generally made one to three probes on each diet. For ease of explanation, results are presented by diet type (steps, or rows, in Table 1), rather than by experiments (columns in Table 1).

1st clearing diets. Insects on the 1 st (postacquisition) clearing diets produced copious, obvious amounts of runny liquid from their labial tips during frequent labial dabbing and probing; the liquid solidified to form visible, solid deposits on the surface of the parafilm diet covers and through the parafilm. All 14 insects from the three experiments were observed on the 1st clearing diets (Table 1, step 2). Insects made numerous labial dabs, but only one to three stylet probes each (total 24 probes, mean 1.7 probes per insect), usually progressing directly into ingestion. Probes lasted between 1 and $37 \mathrm{~min}$ each (total of $189 \mathrm{~min}$, mean $12.6 \mathrm{~min}$ per insect). Thus, all insects spent less than $40 \mathrm{~min}$ probing out of the $60 \mathrm{~min}$ access period.

Heads of all insects fed 1st clearing diets were found to be negative for $X$. fastidiosa GFP via qPCR (detection limit of ca. 50 cells). Likewise, results were negative (for either $X$. fastidiosa GFP or wild-type $X$. fastidiosa) for diet cultures. However, in striking contrast to the PCR and culture results, large amounts of $X$. fastidiosa GFP were seen in 47 CLSM images of 95 surface deposits on or in parafilm covers (Fig. 2) examined from seven insects (numbered 1 through 7, Table 1, step 2, and Table 2). Most deposits were flat and two-dimensional in the shape of elongated smears (Fig. 2A and B) or sometimes rounded globs (Fig. 2G) on the outer parafilm surface, with no puncture of the parafilm. Much less commonly (11 deposits), small partial salivary sheaths (Fig. 2C and D) could be seen surrounding stylet-punctures in the parafilm. Hereafter, surface-only deposits of any shape will be termed 'dabs' and deposits surrounding parafilm punctures will be termed 'sheaths.' Surface dabs were colored a combination of (i) green (Fig. 2A) indicating copious quantities of bacteria, probably in "sticky" EPS/adhesin matrix and/or nonautofluorescent watery saliva (see Discussion), (ii) red (Fig. 2E and F) indicating highly autofluorescent, hardened, viscous gelling saliva (see Discussion), or (iii) yellow (Fig. 2B) overlay color, thus colocalized $X$. fastidiosa GFP bacteria embedded in viscous gelling saliva. Yellow dabs often had red or green striations and red edges (Fig. 2B).

2 nd clearing diets. The five insects on the second postacquisition (2nd clearing) diets (Table 1, step 3) behaved similarly to those on the 1 st clearing diets, moving and secreting copious fluids from their stylets. However, these insects often required a longer time sitting or moving in the diet chamber before the first probe, compared with those on the 1 st clearing diets; thus, observations lasted for $2 \mathrm{~h}$. The five insects whose parafilms were examined (numbers 7 through 11) again made one to three probes each ( 9 total, mean of 1.8 per insect) for 2 to $6.5 \mathrm{~min}$ each ( $21 \mathrm{~min}$ total, mean of 4.2 min per probe).

After insects spent no more than $4 \mathrm{~h}$ on the 2nd clearing diets, all of their heads were negative for GFP or X. fastidiosa via qPCR. Additionally, CLSM examination of two insects' foreguts proved
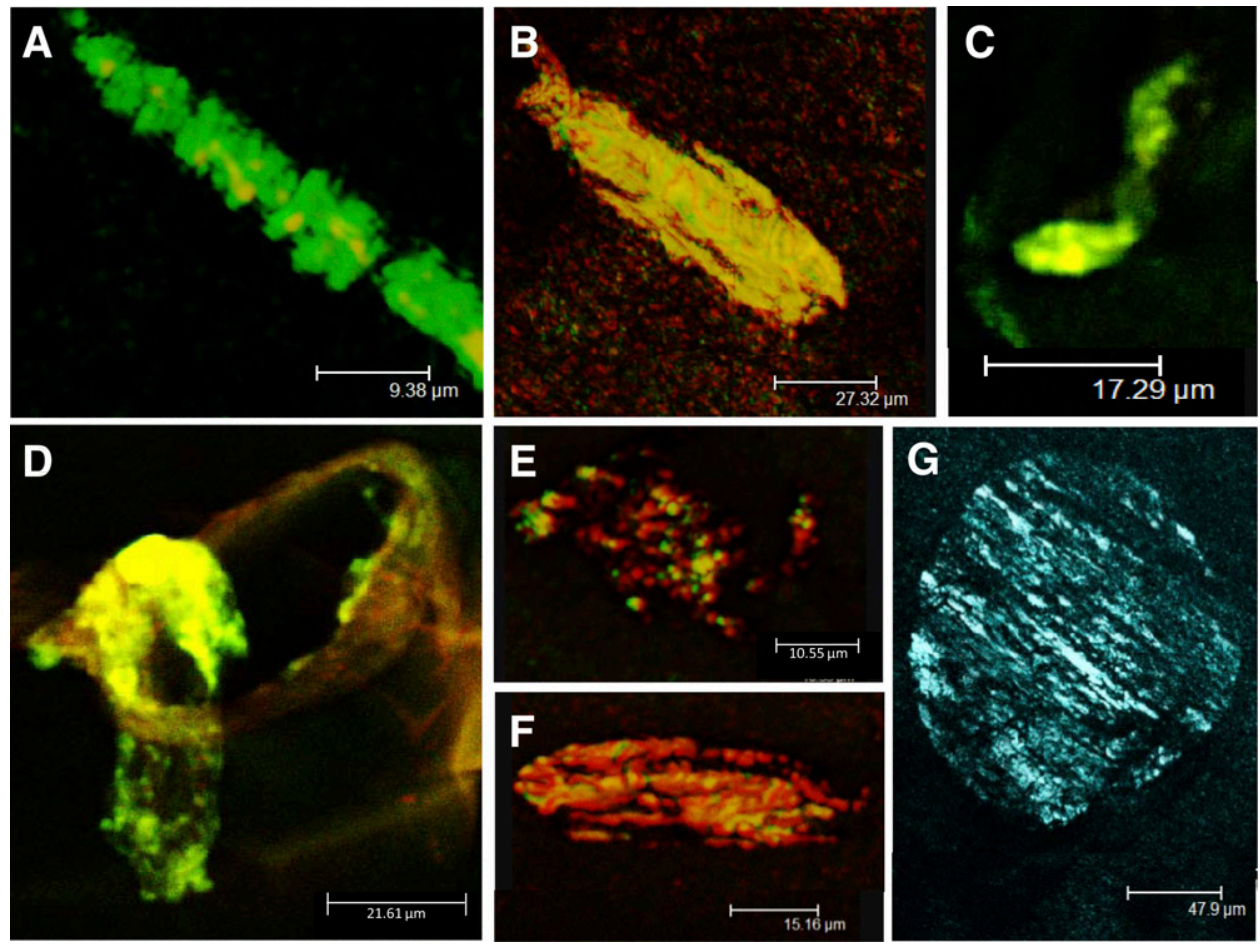

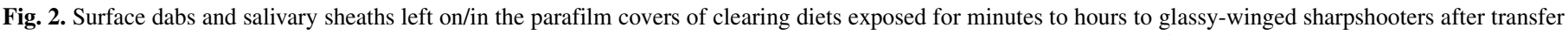

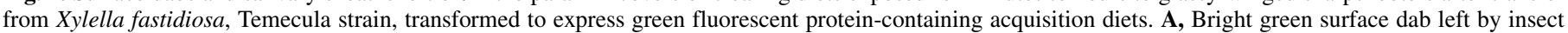

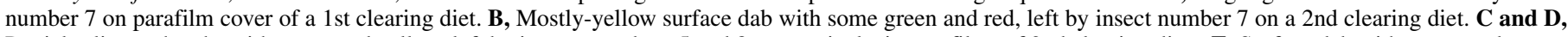

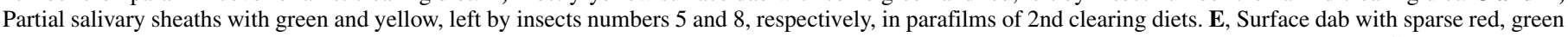

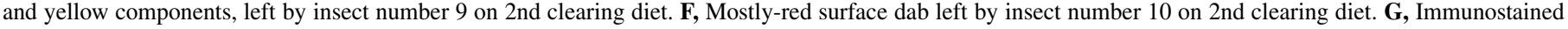
surface dab left by insect number 5 on 1 st clearing diet. 
negative, and 2nd clearing diet culture results were negative. However, similar to parafilms from 1st clearing diets, parafilms from 2nd clearing diets had surface dabs (60 total; 6.0 per insect) and short salivary sheaths (9 total; 1.8 per insect) containing $X$. fastidiosa GFP. Interestingly, smaller amounts of $X$. fastidiosa GFP were seen in saliva on 2nd clearing diets; most deposits on the outside of parafilms were red with variable amounts of green and/or yellow (Fig. 2E and F). Four out of nine salivary sheaths inside parafilm showed green signal (Fig. 2C shows the brightest of these).

Post-cowpea diets. Following the in vitro AAP, some insects were moved onto a cowpea plant for $24 \mathrm{~h}$, and then to the postcowpea diet. These insects behaved differently from insects on the other diets. They did not perform extensive labial dabbing and each began probing soon after arrival in the diet chamber. In the case of the insects whose diet parafilms were later examined, two insects made one probe each (numbers 12 and 13, for 10 and $2 \mathrm{~min}$, respectively) and the third insect (number 14) made three probes (total five probes observed, mean 1.7 probes per insect) lasting 3 to 21 min (mean 6.3 min per insect).

Following observation on the post-cowpea diets, all insect heads were dissected and tested via qPCR; again, all heads were negative at the same detection limit. Cultures of diets from the post-cowpea diets were all negative for any type of $X$. fastidiosa. The cowpea plants used for multiplication were likewise all negative for either $X$. fastidiosa or GFP (detection limit of ca. 50 cells per sampled leaf). CLSM examination of the post-cowpea diet parafilms revealed only eight surface dabs (only 1.5 per insect) from the three insects (Table 2, insects 12,13, and 14) and nine salivary sheaths within parafilms. One insect made only a single, short salivary sheath and left no surface dabs; therefore, its results were not included in the statistical analysis or Table 2. Most of the very small dabs were red in the CLSM examination, with variable evidence of $X$. fastidiosa GFP (images not shown, but similar to others).

Immunohistological analysis of surface dab images from experiments 1 and 2. To independently confirm that GFP detected on/in diet parafilms represented $X$. fastidiosa, four parafilm diet covers (one each from insects 3 through 6 ) were immunostained for $X$. fastidiosa. Four partial salivary sheaths through the parafilm (1.0 per insect) and 27 surface dabs (6.8 per insect) were identified (Fig. $2 \mathrm{G}$; saliva false-colored blue for bacteria and red autofluorescence for saliva, giving blue-green to white overlay colors). Thus, GFP in salivary deposits definitively represented $X$. fastidiosa bacterial cells in saliva.

Quantitative analysis of surface dab images from experiments 1, 2, and 3. 1st clearing diets. Parafilm diet covers from the 1st clearing diets of experiments 1 and 2 (combined) had a variable but large number of surface dabs (95; Table 2), with an average of 13.6 dabs per insect. Area of dabs was also large but highly variable. Mean dab area per image by individual insect varied from a low of just under $1,000 \mu \mathrm{m}^{2}$ (insect 2) to over 11 times as large (insect 6) (Table 2). Mean areas by insect (within experiment 1$)$ were significantly different overall $(F=3.58$, df $=$ $13,60 ; P=0.0004)$, with dab areas of insects 3 and 7 significantly larger than those of insect 2 , and those of insects $1,4,5$, and 6 intermediate (Table 2).

Color separation and quantification for surface dabs on the 1st clearing diet parafilms were striking for their relative uniformity and abundance of green (bacteria) in most dabs. Overall treatment averages per insect showed $84.7 \pm 2.7 \%$ of dab area was green, with less than $10 \%$ each for red and yellow (Fig. 3; $9.0 \pm 1.5 \%$ red and $6.3 \pm 1.5 \%$ yellow). There was no significant difference among insects for percent green salivary areas per image, despite numerical percentages ranging from just under 70 to $100 \%$ of the areas being green. Dab areas from two insects (numbers 1 and 2; total of nine dabs) were $100 \%$ green. Differences among insects were significant $(F=3.00, \mathrm{df}=6,400 ; P=0.0163)$ for red percentages, but not for yellow percentages.

2nd clearing diets. Numerically fewer (60) surface dabs were left on 2nd clearing diet parafilms from experiment 2 with an average of 12 dabs per insect. Mean dab areas per image by insect were more uniform (ranging from 8,000 to just over $15,000 \mu \mathrm{m}^{2}$ ) than on the $1 \mathrm{st}$

TABLE 2. Surface dab area data ${ }^{\mathrm{z}}$

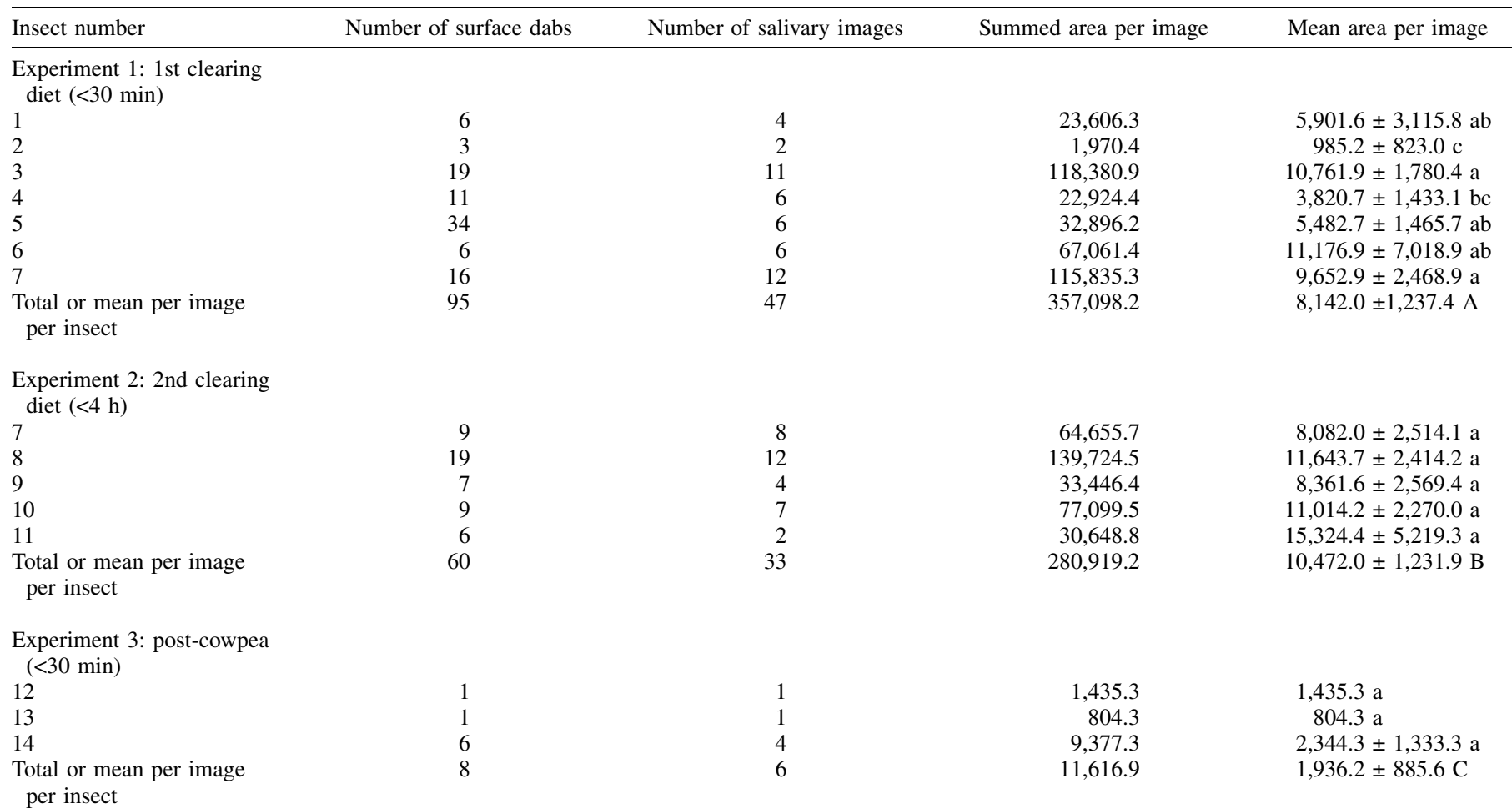

$\mathrm{z}$ Total number of surface images and surface dabs contained therein, for each examined insect's diets from experiments 1, 2, and 3. Also included are the summed area and mean area per image for each insect, each averaged across all insects in each treatment. Means for insects are not significantly different if followed by the same lowercase letter (for within experiments) or uppercase letter (for among experiments). $\alpha=0.05$ for all comparisons. 
clearing diets, with no significant difference among the dab areas of the five insects examined (Table 2). Quantitative color separation for the surface dabs on the 2 nd clearing diet provided different results from the 1st clearing diets, supporting initial visual observations (Fig. 2 ). In contrast with the 1 st clearing diets, on average, $54.2 \pm 4.9 \%$ of the areas of 2 nd clearing diet surface dabs were green, while $21.0 \pm$ $4.7 \%$ were red and $24.8 \pm 3.3 \%$ were yellow (Fig. 3). Seventy-nine percent of the salivary areas per image (on average) were filled with bacteria, numerically almost as high as those on the 1st clearing parafilms. Yet there was also a higher percentage of red in the 2 nd clearing diet dabs compared with those on the 1st clearing diets. Similar to 1 st clearing diet dabs, percentages were significantly different among insects $(F=12.55, \mathrm{df}=4,28 ; P<0.0001)$ for red, but not for green or yellow.

Brief mention should be made of the single insect (no. 7) whose surface dabs were imaged in two experiments. Relative percentage of dab area for total bacteria (yellow plus green) was about the same on both diets (92 to $94 \%$ ). However, percentage of green (bacteria not embedded in viscous gelling saliva) decreased by $17 \%$ from 1 st clearing to 2 nd clearing diets, while percentage of yellow (embedded bacteria) increased 19\%, suggesting that as time progressed in the $24 \mathrm{~h}$ after the AAP, more and thicker salivation became increasingly important in order to loosen bacteria before expulsion.

Post-cowpea diets. Areas of surface dabs for the post-cowpea diet parafilms (i.e., after $30 \mathrm{~min}$ of diet access following $24 \mathrm{~h}$ of post-AAP feeding on a cowpea plant) were strikingly lower than those of the previous treatments. Only eight dabs, of much smaller size, were located on three parafilms exposed to four insects. The fourth insect (number 15) made no surface dabs, only a single, very small red salivary sheath surrounding a parafilm puncture. Two insects (numbers 12 and 13) made only one surface dab each, of small size. Insect 14 made six slightly larger dabs. However, none of the dabs were significantly different in area (Table 2).

Color separation results for the post-cowpea diet parafilms also were very different from the other two treatments. Despite great variability among the insects for dab area (Table 2) and color percentages, average dab area probably best represented postcowpea diet parafilms. The highest mean percentage of dab area $(67.3 \pm 11.9 \%)$ was red, with $23.4 \pm 11.2 \%$ green, and only $9.3 \pm$ $3.4 \%$ yellow (Fig. 3). Thus, less than one third of the alreadysmall salivary area per image (about $20 \%$ of per-image averages in the first two treatments) had bacteria after insects spent $24 \mathrm{~h}$ on a plant.

Comparison among diets. The per-insect means for each experiment were significantly different from one another, for both dab area and color separations. Mean dab area per image per insect was highly significantly different (indicated by uppercase letters in Table 2) $(F=12.02, \mathrm{df}=2,83 ; P<0.0001)$, with the average dab area on 2 nd clearing diet parafilms significantly higher than that on 1st clearing diet parafilms and, especially, post-cowpea diets (Table 2). Red percentage in surface dabs increased significantly $(F=20.03, \mathrm{df}=2,71 ; P<0.0001)$ with each successive experiment (Fig. 3); the significantly highest percentage (67.3\%) was on the post-cowpea diet parafilms, significantly intermediate $(21.0 \%)$ on 2nd clearing diet parafilms, and significantly lowest (9.0\%) on 1st clearing diet parafilms. Conversely, green percentage declined significantly $(F=28.19$, df $=2,71 ; P<0.0001)$ with each successive treatment; 1st clearing diet parafilms had the highest percentage green $(84.7 \%)$, 2nd clearing diets were intermediate $(54.2 \%)$, and post-cowpea diet parafilms were lowest $(23.4 \%)$. Interestingly, yellow occupied the significantly $(F=18.60, \mathrm{df}=2$, $71 ; P<0.0001)$ highest mean salivary area per image on 2 nd clearing diet parafilms (though still numerically low, about one quarter) (Fig. 3), while yellow percentages on both 1st and postcowpea diet parafilms were low and not significantly different from one another (less than 10\%). The combined bacterial percentages declined significantly $(F=20.03$, df $=2,71 ; P<$ 0.0001 ) with successive treatment; from $90.9 \%$ on the 1 st clearing diet, to $79.0 \%$ on the 2 nd clearing diet, and a large fall to $31.1 \%$ on the post-cowpea diet.

Thus, high percentages of green without red or yellow occurred on the first treatment, the 1st clearing diet. Total bacterial area per insect (i.e., mean percent bacteria per insect, times summed area [both per treatment], divided by the number of insects in the treatment) was $46,371.8 \mu \mathrm{m}^{2}$ on the 1 st clearing diet. The 2 nd clearing diet dabs had somewhat lower percentage of green, but mixed with moderate percentages of red and yellow. The total bacteria area per insect on 2nd clearing diets was $44,385.2 \mu \mathrm{m}^{2}$ (95.7\% of the first treatment). Percentages of areas in the surface dabs on the post-cowpea diet parafilms were highly variable but mostly red with some green and a little yellow. Yet because the salivary dabs on the post-cowpea diet parafilms were very small, i.e., their areas were severely decreased compared with the 1st clearing diets (Fig. 3, represented by size of pies), total bacterial area per insect in this third experiment was only $1,204.3 \mu \mathrm{m}^{2}(2.6 \%$ of the first experiment).

Experiment 4. Sharpshooters probed water diet with green fluorescent nanoparticles for less than $30 \mathrm{~min}$. Immediately thereafter, they were placed on air-filled parafilm chambers into which they probed and created long, structurally complex salivary sheaths. Fluorescent signal from nanoparticles was never seen in the salivary flange (Fig. 4A, D, G to K, white arrows), i.e., the portion of the air-formed salivary deposit left on the outside of the parafilm cover (the insect side). The flange was confluent with and connected to the salivary sheath. However, in all cases where green fluorescent nanoparticles were included in the water diet, fluorescent signal was emitted from variable parts of the air-formed salivary sheaths (Fig. $4 \mathrm{D}$ to $\mathrm{F}, \mathrm{J}$, and $\mathrm{K}$ ). In contrast, salivary sheaths from insects on control diets lacking nanoparticles did not fluoresce (Fig. 4L). In some cases (Fig. 4J), green fluorescence was clearly emitted from the interior of and distributed throughout the sheath material, from the base (trunk), middle, and tip of the sheath (Fig. 4G and J, yellow, red, and black arrows, respectively). In other cases, fluorescence was only seen in the trunk (Fig. 4D), and not the middle (Fig. 4E) or tip (Fig. 4F) of the sheath. Figure 4H (bright-field) and Figure 4K (green filtered fluorescence) show an aborted sheath with only the sheath trunk present, but brightly fluorescing green (yellow arrow). Spectral sensitivity of the green filter used strongly supports that the green fluorescent signal in saliva was derived from the green fluorescent nanoparticles in diets; absence of green fluorescent signal in saliva from insects fed water diet lacking nanoparticles supports the same conclusion.

\section{DISCUSSION}

Implications for the transmission mechanism of X. fastidiosa. Acquisition. The established protocol to achieve $X$. fastidiosa-free sharpshooters for transmission experiments has been to rear insects on $X$. fastidiosa-free plants replaced once per week (2). Scanning electron microscopy of vector foreguts shows bare cuticle in blue-green sharpshooters, Graphocephala atropunctata (Signoret) (2) reared in this manner. However, with the exception of one paper (9), similar microscopical examination is not typically performed for studies with glassy-winged sharpshooter. Instead, transmission tests $(28,33)$ with colony insects have been used to confirm absence of $X$. fastidiosa prior to experiments. However, while useful, negative transmission tests cannot definitively show absence of $X$. fastidiosa.

The present study demonstrated via qPCR that rearing both fieldcollected and colony glassy-winged sharpshooters on uninfected host plants changed weekly indeed reduces numbers of $X$. fastidios $a$ cells in vector heads to undetectable levels. However, subsequent CLSM examination of such sharpshooters (herein and in [9]) revealed the abundant presence of unknown (but non- $X$. fastidiosa) 
$2^{\text {nd }}$ Clearing Diet

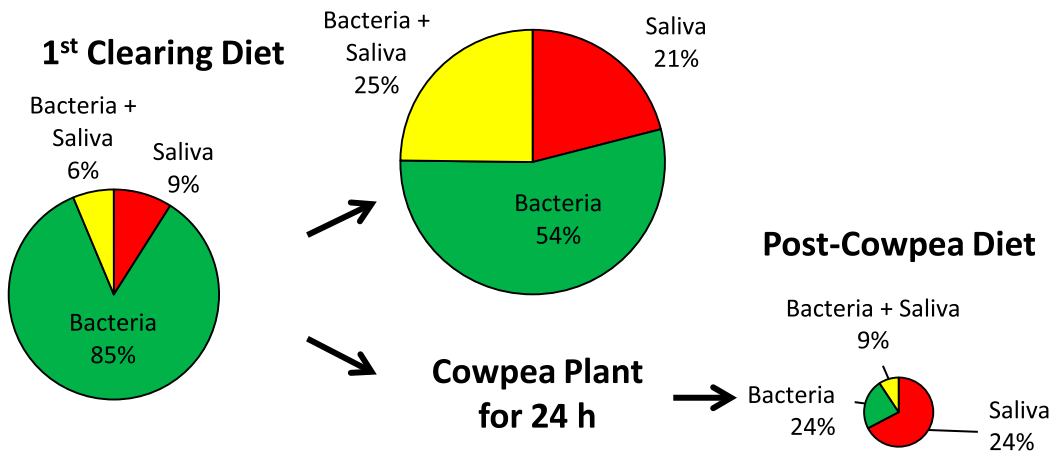

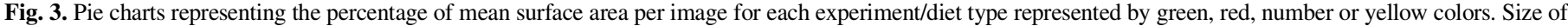

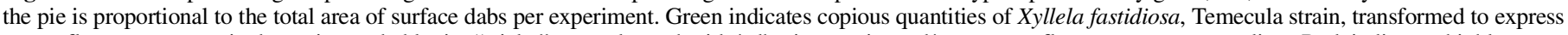

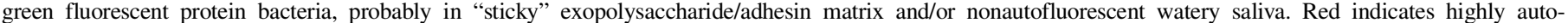
fluorescent, hardened, viscous gelling saliva. Yellow is the overlay color, and thus represents colocalized bacteria embedded in viscous gelling saliva.
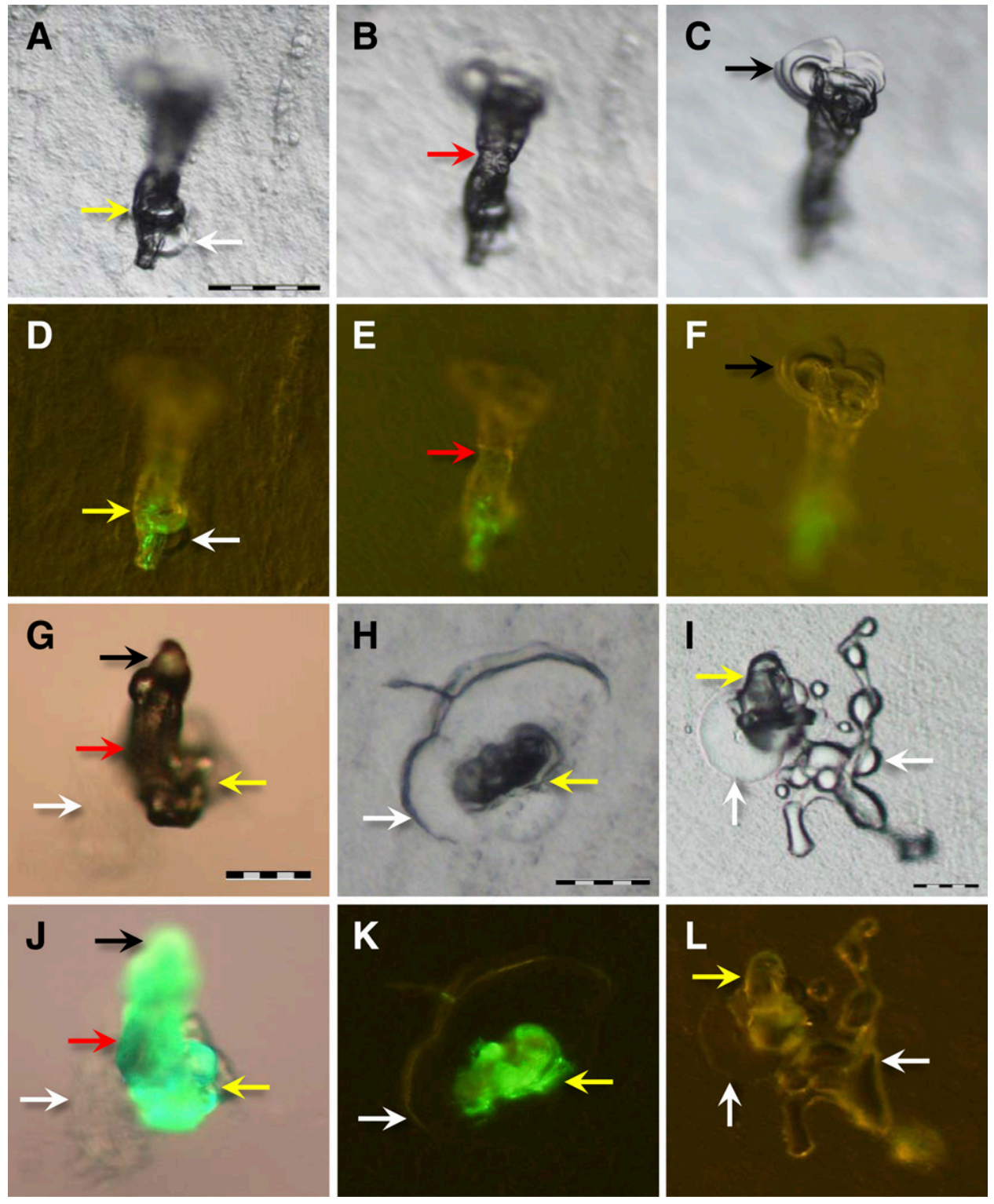

Fig. 4. Stereoscan images of air-formed salivary sheaths of glassy-winged sharpshooters after feeding for $<30 \mathrm{~min}$ on artificial diet with green fluorescent nanoparticles. A to F, Different focal planes of a single air-formed sheath from the base (A and D, yellow arrow), midsection (B and $\mathbf{E}$, red arrow), and top of the sheath (C and $\mathbf{F}$, black arrow). A, B, and $\mathbf{C}$ are brightfield views and $\mathbf{D}, \mathbf{E}$, and $\mathbf{F}$ are UV-excited filtered green fluorescence. $\mathbf{D}$, Green fluorescence is limited to the base of the air-formed sheath. H, Bright-field and $\mathbf{K}$, green filtered fluorescence views of an aborted sheath with a trunk/base present having green fluorescence (yellow arrow). I, Bright-field and $\mathbf{L}$, green filtered fluorescence views of a sheath control (thus, minus the nanoparticles) that indicates the absence of green fluorescence (L) when illuminated by UV light and filtered for green fluorescence. White arrows (A, D, and G to L) indicate the flange of the air-formed sheath, on the outside of the plastic wrap. 
microbes in the same sites in the foregut to which $X$. fastidiosa usually adheres. In fact, as shown herein for the first time for any foregut-borne organisms, these unknown microbes were even found in the stylet food canal. The unknown microbes apparently increased in numbers to fill the space vacated by $X$. fastidiosa. Recently, glassy-winged sharpshooters from the same colony as used for the present paper were found to have a large array of bacterial species in their foreguts (49).

Why did we see (essentially) no $X$. fastidiosa adherence to either cuticle or resident microbes in the foregut? There are several possibilities: (i) bacteria never adhered to cuticle or alreadyresident unknown microbes, or (ii) any cells that adhered to cuticle or other microbes: (a) were few in number and $24 \mathrm{~h}$ was not sufficient time for them to multiply and colonize the area sufficiently to be detectable, or (b) became dislodged and were ejected back out the stylets while insects were still on the acquisition diet. Not (originally) anticipating that bacteria would be found in surface dabs, we did not examine parafilm covers of the acquisition diets. Thus, it cannot be determined whether putative dabs on acquisition diets may have had $X$. fastidiosa GFP in them.

Inoculation: The evidence for egestion. It has been speculated ever since the discovery (48) of $X$. fastidiosa in the functional foregut of sharpshooter vectors that egestion (sometimes also termed 'extravasation') was the mechanism of its inoculation $(8,47,48)$. However, direct experimental proof of the existence of egestion, let alone its role in $X$. fastidiosa inoculation, has been lacking until now. Experiment 4 of the present study conclusively demonstrates that large numbers of bacteria-sized nanoparticles (that could only have been derived from the artificial diet) can be taken up by glassy-winged sharpshooters after no more than $30 \mathrm{~min}$ of observed stylet probing. These nanoparticles must be held in the foregut (because it is the only receptacle large enough to hold a sufficient volume of nanoparticle-laden fluid, presumably without nanoparticles adhering to the cuticle). The nanoparticles can be held for at least several seconds to minutes, inside the insect, while the insect is transported to the second diet. The mixture of nanoparticles and diet (possibly also watery saliva, see below) was then ejected into gelling saliva simultaneously secreted from the stylet tips that hardened into a salivary sheath. It is not possible that such non-cuticle-adhering nanoparticles could become circulative, as is the case of many insect-transmitted viruses (42). In other words, nanoparticles cannot bind to specific receptors in the gut epithelial cell membranes, be endocytosed into the cells, exocytosed into the hemolymph, circulate to the salivary glands, be similarly taken up and expelled by those cells, and then secreted out through the salivary canal in the stylets, let alone in such a short time. Considering this, egestion of a column of fluid (held and not swallowed) from the foregut out the stylet tips is the only possible explanation for our experiment 4 results.

In similar fashion, no evidence has ever been found that $X$. fastidiosa is circulative in vector hemolymph. Within the $24 \mathrm{~h}$ AAP in experiments 1 to 3 , every surviving sharpshooter must have ingested (i.e., swallowed past the cibarium into the pharynx, esophagus then midgut) the bacteria-laden diet, or the insect would have died. Most bacteria that were taken up by the insect presumably were swallowed and ultimately excreted. A fraction of the total $X$. fastidios $a$ GFP that were acquired during the AAP had to be carried inside the insects as they were transferred from the acquisition diets to the 1st clearing diets. Subsequently, these bacteria were deposited in surface dabs or small salivary sheaths on parafilm diet covers. The bacteria must have come from the foregut, because they could not circulate into the salivary glands yet were not swallowed and excreted. Salivary sheaths were small on the clearing diets because the sharpshooters, once they finally probed the unfamiliar membrane, did not have to search for xylem sap.

Unlike nanoparticles, bacteria provide an added dimension to this story, because they are capable of adhering to and colonizing the cuticle-lined anterior foregut. Backus and Morgan (9) show that $X$. fastidiosa GFP colonies bound to cuticle in the precibaria and cibaria (oral cavity) of glassy-winged sharpshooters can slowly expand in area and location over several days, ultimately occupying the full length of the precibarium. The same bacterial colony can then suddenly and almost completely disappear in a single $24 \mathrm{~h}$ period from the entire precibarium, even though the vectors continued to feed on $X$. fastidiosa-infected grape plants. In the present study, large amounts of $X$. fastidiosa GFP were swept out of the foregut within $40 \mathrm{~min}$ after transfer to the 1 st clearing diet, leaving an undetectable amount of $X$. fastidiosa cells in the insect. If the large amount of $X$. fastidiosa GFP we found in surface dabs had adhered to the foregut before being carried to the clearing diets, the bacteria had to have been swept away very quickly and completely. The fluid turbulence during egestion may be powerful enough to loosen and sweep all bacteria out, especially when combined with the loosening activity of watery saliva (see below) over a $24 \mathrm{~h}$ test period (9). However, the present work points toward an alternative hypothesis, elaborated below.

Backus and Morgan (9) provide circumstantial evidence for the existence of egestion. When combined with the present, more definitive evidence, the proof is now very strong that $X$. fastidiosa cells in the precibarium (thought to be the "staging area" for expulsion [2,8]) are inoculated into a food source (39) via egestion.

Inoculation: Salivation. Another fascinating finding from the present study is that egested GFP-transformed X. fastidiosa can become encased in hardened gelling saliva; thus, egestate from sharpshooters can be a mixture of liquid food and saliva. All hemipterans once were thought to secrete two entirely different and separate types of saliva $(39,40)$ : (i) enzymatic, dispersive, lowviscosity watery saliva, and (ii) nonenzymatic, solidifying gelling saliva that forms the salivary sheath surrounding the penetrating stylets. Gelling saliva produced by glassy-winged sharpshooters is highly autofluorescent in CLSM, while watery, dilute, enzymatic saliva is not (6). Immunohistochemical staining of $\beta-1,4$-endoglucanase and related carbohydrases in watery saliva, spectrally separated from autofluorescence of gelling saliva, shows that watery saliva carrying enzymes can be secreted simultaneously with varying amounts of gelling saliva, leaving salivary sheaths composed of both types of saliva (6). A different study at the same time showed similar findings for aphid saliva (40). Composition of saliva is apparently voluntarily controlled by the insect, as there are innervated muscle strands around the lobes of leafhopper salivary glands (3). Because enzymes from watery saliva can become embedded within gelling saliva, anything loosened by enzymatic action (e.g., bacterial cells) can end up encased in hardened salivary sheaths.

A mechanism for watery saliva mixing with food comes from two properties of sharpshooter foregut anatomy that are strikingly different from those of aphids. In aphids, the food and salivary canals inside the stylets conjoin to form a common canal at the maxillary stylet tips before a single exit hole $(20,54)$. Outgoing watery saliva and incoming food can mix in the common canal, and the food-saliva mix can then be sucked up directly into the food canal and ingested, without injecting the mixture into the plant (53). In contrast, the food and salivary canals are entirely separate in sharpshooter stylets (35). Two exit holes for the two canals occur at the tips of the much-larger maxillary stylets of glassy-winged sharpshooters, whose stylet lengths are easily 20 times longer than those of most aphids. Thus, there is no physical way for sharpshooter saliva to mix with food before being secreted outward from the stylet tips. It is reasonable that two mechanisms would exist in sharpshooters for mixing of watery/gelling saliva with food. In one mechanism, watery saliva is first secreted into the food source, then a mixture of food and saliva is actively sucked up into the stylet food canal and/or the oral cavity (to be tasted by the precibarial chemosensilla [4]); then the mixture is egested back out the stylet tips, where it further mixes with newly secreted gelling saliva. In this case, the food/watery saliva mixture could enzymatically assist in dislodging any bacteria attached within the anterior foregut. Alternatively, food alone is sucked up into the precibarium, and then is egested out the food canal 
simultaneously with secretion of watery saliva from the salivary canal. Additionally-secreted gelling saliva plus the food/watery saliva mixture then combine at the tip of the stylets in the food source. In this alternate case, watery saliva would not be taken up the food canal into the functional foregut.

Given these findings, uptake of watery saliva and its subsequent egestion best explains the findings of Backus and Morgan (9) regarding $X$. fastidiosa. The extreme scrubbing clean of cuticle seen in their images of the precibarium suggests that enzymatic saliva dissolves the complex EPS/adhesin matrix adhering bacteria to the cuticle (6), prior to egestion of the bacteria/food/saliva mixture. The polysaccharide-degrading enzyme $\beta$-1,4-endoglucanase and other, related enzymes (with exactly the required functions to dissolve bacterial EPS matrix) are secreted in glassy-winged sharpshooter saliva (6). That said, there is no reason why the insect cannot perform all mechanisms of salivary mixing. Thus, the uptake of a mixture of watery saliva and food into the oral cavity, followed by egestion back out into the plant combined with more mixing into newly secreted watery and sheath saliva, is the best explanation for inoculation of cuticle-adhering, colonized X. fastidiosa.

Acquisition and inoculation revisited: Hypothesis for an alternate mechanism that explains absence of a latent period. Our findings also suggest an entirely different explanation for transport of nanoparticles or bacteria inside the insect from diet to diet. Instead of adhering directly to foregut cuticle during trips between host plants, particles or bacteria could be suspended in a column of fluid held by the insects in their tube-like functional foreguts. A transported fluid column seems to be the most parsimonious explanation for all of our experimental results, but especially our experiment 4 findings, because a large number of (presumably nonadhering) nanoparticles must be transported to cause the strong fluorescence seen in many salivary sheaths of experiment 4 . For experiments 1 to 3 , it is possible that insects probing and ingesting for $24 \mathrm{~h}$ on the acquisition diet could have kept a column of fluid in their stylets and foreguts when they were abruptly pulled off the diets. Once the insects were encased in the 1st and 2nd clearing diet chambers, they then could have egested the column of fluid into surface dabs, as they searched for plant-like stimuli in the sterile environment of the chamber. This explanation seems more (if not at least equally) likely than the hypothesis that hundreds to thousands of bacterial cells adhered to the cuticle (or resident microbes) during the $24 \mathrm{~h}$ acquisition feed, and then suddenly (within seconds to minutes after arrival in the clearing diet chambers) virtually all of them were loosened and egested out of the stylets.

While the present study does not provide definitive evidence of bacteria being suspended in a column of fluid held in the foregut as the insect is being transferred from diet to diet, circumstantial evidence is sufficient to warrant a future study to test this concept. We therefore propose the hypothesis that a sharpshooter can, at (perhaps rare) times, be a true flying syringe (10) (in the sense that the narrow, tube-like foregut acts like a syringe holding fluid that is ejected before suspended bacteria can adhere with specificity to the walls of the syringe). Thus, in the first few seconds to minutes after uptake of bacteria-laden fluid, purely mechanical transport of bacteria in fluid between adjacent feeding substrates might occur. Such a circumstance clearly fits the definition of a flying syringe, justifying resurrection of the old term as appropriate for our model. We also hypothesize that egestion of bacteria-laden fluid could explain the absence of a latent period (in laboratory experiments) for $X$. fastidiosa.

Our flying syringe mechanism of inoculation could be the first step of a temporal process ultimately leading to $X$. fastidiosa bacterial colonization of the sharpshooter foregut. Although bacteria clearly can adhere to insect cuticle (or other microbes) eventually, such adherence to cuticle probably cannot be instantaneous. It is likely that a gradual transition could occur. The process could start with bacteria held in a column of fluid, then progress to a portion of bacteria adhering to the cuticle (and therefore "acquired" in the traditional sense), to all bacteria adhered, to complex biofilm formation. Multiplication could occur at any of the above stages.

Interpretation of surface dab colors and implications. The above information helps us interpret the dab color results of experiments 1 to 3 . If suspended $X$. fastidiosa GFP bacteria were held in a column of diet fluid in the foregut, the fluid could be egested without (or with very little) mixture with watery and gelling saliva. For dabs on the 1st clearing diets, we propose that the bright green surface dabs were mainly composed of such held-fluid egestate, i.e., a mixture of $X$. fastidiosa GFP in aqueous diet with their own, secreted EPS/adhesin cement (large amounts of which are stimulated by culturing on XFM+pectin medium (31), and which can be chemically fixed by paraformaldehyde but probably not enough to autofluoresce). For dabs on the 2 nd clearing diets, it is logical that the yellow surface dabs were created because (by 3 to $4 \mathrm{~h}$ after the 1 st clearing diet after AAP) any bacteria not yet expelled were beginning to adhere to the foregut cuticle or the unknown, resident microbes. $X$. fastidiosa GFP were then loosened by secretion and uptake of watery saliva to the oral cavity. The diet/bacteria/ watery saliva mixture was then egested out to mix with additional, simultaneously secreted gelling saliva. This explains why the yellow dabs were almost a 50:50 mixture (on average) of $X$. fastidiosa GFP (probably mixed with a slurry of EPS and nonautofluorescent watery saliva) colocalized with autofluorescent gelling saliva. For dabs on the post-cowpea diet, very few bacteria were left in the precibarium after clearing on a plant for $24 \mathrm{~h}$. The insect would still secrete watery and gelling saliva on the surface and suck it up to the precibarial chemosensilla. Egested watery saliva would mix with further secretion of gelling saliva to yield small, highly autofluorescent, solidified red dabs of gelling saliva.

Thus, the progression of colors in surface dabs from 1st to 2 nd clearing diets, or from 1st clearing diet to cowpea to post-cowpea diet, supports a progression from egested fluid column with suspended bacteria, to egested detached bacteria in saliva, to (smaller amounts of) egested saliva with very few bacteria, respectively. Over time, more salivation was required to eject smaller amounts of bacteria. This suggests that bacteria began to adhere to the foregut cuticle but were dislodged by enzymatic activity of saliva, leaving undetectable amounts remaining in the foregut for $\mathrm{qPCR}$ detection of heads. The precibarium apparently can be both enzymatically and mechanically "scrubbed clean," as seen in Backus and Morgan (9).

The results from experiment 4 (in which the salivary sheaths resembled more closely those seen inside probed host plants) can be similarly explained. The salivary flange (on the outer surface [insect side] of the parafilm) was created by secreted gelling saliva (probably mixed with some watery saliva) in absence of egestion. With only a few minutes on the water/nanoparticle diet, these insects likely were not yet ingesting in a sustained manner, as the experiments 1 to 3 insects were on the acquisition diet (for $24 \mathrm{~h}$ ) before they were removed. Thus, experiment 4 insects probably took up a small amount of water/nanoparticle diet for tasting only, and added new watery saliva to that held-fluid during labial dabbing. It was not necessary to expel the held-fluid prior to probing, thus no nanoparticles were in the flanges. As the experiment 4 insects' stylets punctured through the parafilm, fluorescent nanoparticles (probably held in the small fluid column inside the foregut) then were egested out, simultaneous with secretion of more gelling saliva, to mix into and form the nanoparticle-fluorescent salivary sheath. Sometimes a large volume of nanoparticle-suspended diet was held and egested into the full length of the salivary sheath. Other times, a smaller amount was egested, to mix with only the basal portion of the sheath.

In an analogous fashion, if an insect holding a large quantity of bacteria-laden fluid in its foregut begins probing a plant, X. fastidiosa could be egested into the full length of a salivary sheath. Because previous work (6) shows that a combination of watery and gelling saliva is directly ejected into xylem cells, bacteria would enter the xylem in that case. If only a small amount of bacteria-laden 
fluid is held, it might be injected into only the base of the salivary sheath along the pathway, thus bacteria would be expelled before a xylem cell is reached. In both cases, bacteria would be ejected, therefore inoculated, into the plant. However, the epidemiological consequences could be quite different in each case. Direct inoculation into xylem could, presumably, lead to infection. Inoculation into nonxylem cells might not.

The present research conclusively proves the existence of egestion by the glassy-winged sharpshooter, a process that other hemipterans may also perform. We suggest that a salivationegestion inoculation mechanism also may be plausible for aphidtransmitted nonpersistent viruses, as suggested by Harris and Harris (26). Virions bound to the acrostyle in the common food-salivary canal tip of aphids $(54,55)$ could be egested outward, just as likely as salivated outward. However, it probably would be very difficult to prove experimentally that either salivation or egestion is occurring for aphids, requiring an experimental design even more exacting than the present study.

Summary and answers to original questions. The answer to our first question (How do bacteria come out of the stylets?) is clear when the present results are combined with those from previous studies $(6,7)$. Our work conclusively demonstrates that $X$. fastidiosa can be egested from the vector's foregut, mixed with watery (and often also gelling) saliva that is secreted from the stylets. Support is now very strong for the salivation-egestion hypothesis (7) for inoculation of $X$. fastidiosa.

We propose that the answer to our second question (Why is there no latent period between acquisition and inoculation?) requires reconsidering an old paradigm. We hypothesize that, for $X$. fastidiosa inoculation, sharpshooter vectors could (at times) be true flying syringes (10) by virtue of carrying a volume of fluid (potentially with suspended bacteria) in their foreguts when dispersing from plant to plant. At those times, the inoculation mechanism would be nonpersistent.

Although the flying syringe model is technically feasible, its epidemiological implications are presently unknown. It is possible that a nonpersistent, flying syringe mechanism might only rarely operate in the field. For example, in an infected vineyard, large amounts of suspended bacteria may be available in very few xylem cells in a grapevine, making their uptake highly stochastic. On the other hand, a nonpersistent mechanism might be common and epidemiologically important. For example, once a bacterial biofilm-filled xylem cell is encountered during sharpshooter probing, watery saliva injected into the xylem cell might loosen the adhered bacteria, which could then become suspended in xylem sap. Once that sap is taken up in the foregut, fluid retention and transport could be very likely. Probing on adjacent canes on the same vine, or vines in the same row, could easily occur within seconds. Male glassy-winged sharpshooters have been observed to move from plant to plant frequently, probing every few seconds (R. Krugner, personal communication).

It is even possible that $X$. fastidiosa has a bimodal transmission mechanism. Nonpersistent transmission would occur via "acquisition" of suspended bacteria from an infected plant into a fluid column in the foregut held during rapid (seconds to minutes) transit to a nearby healthy cane or vine, whereupon it would be egested outward. If transit times require hours to days, fluid may be held longer and not egested or swallowed. Bacteria could gradually settle out, adhere to the cuticle wall, form biofilm, colonize and (over several days) spread throughout the functional foregut (9). The next plant probed would be inoculated by combined salivation and egestion, for a persistent (in adults) mechanism. While bimodal transmission mechanisms are considered rare, they have profound implications for epidemiology and disease management. Nonpersistent pathogen vectors are typically actively-dispersing noncolonizers, while persistent pathogen vectors are typically colonizers. A bimodal transmission mechanism could be tested via traditional transmission studies. We therefore propose that further study of a flying syringe mechanism of inoculation is warranted.

\section{ACKNOWLEDGMENTS}

$H$. vitripennis were generously provided from a colony maintained by W. Hunter at the U.S. Department of Agriculture (USDA)-Agricultural Research Service (ARS), U.S. Horticultural Research Laboratory at Fort Pierce, FL. We also thank S. Lindow, University of California, Berkeley, for providing the original culture of GFP-transformed X. fastidiosa used in this study. Sharpshooters and plants were reared by C. Cooper and D. Schletewitz, and PCR tests were performed by M. Schreiber (all at ARS, Parlier), whose help is also greatly appreciated. Funding for this project came from in-house ARS support to E. A. Backus and E. E. Rogers. Mention of trade names or commercial products in this publication is solely for the purpose of providing specific information and does not imply recommendation or endorsement by the USDA. USDA is an equal opportunity provider and employer.

\section{LITERATURE CITED}

1. Almeida, R. P. P. 2009. Xylella fastidiosa transmission by vectors-From molecules to models. (Abstr.) Phytopathology 99:S155.

2. Almeida, R. P. P., and Purcell, A. H. 2006. Patterns of Xylella fastidiosa colonization on the precibarium of sharpshooter vectors relative to transmission to plants. Ann. Entomol. Soc. Am. 99:884-890.

3. Ammar, E. D. 1984. Muscle cells in the salivary glands of a planthopper, Peregrinus maidis (Ashmead) and a leafhopper, Macrosteles fascifrons (Stål) (Homoptera: Auchenorrhyncha). Int. J. Insect Morphol. Embryol. 13:425-428.

4. Backus, E. A. 1985. Anatomical and sensory mechanisms of leafhopper and planthopper feeding behavior. Pages 163-194 in: The Leafhoppers and Planthoppers. L. R. Nault and J. G. Rodriguez, eds. John Wiley \& Sons, Inc., New York.

5. Backus, E. A. Sharpshooter feeding behavior in relation to transmission of Xylella fastidiosa: A model for foregut-borne transmission mechanisms. Vector-Mediated Transmission of Plant Pathogens. J. K. Brown, ed. American Phytopathological Society, St. Paul, MN. (In press).

6. Backus, E. A., Andrews, K. B., Shugart, H. J., Greve, C. L., Labavitch, J. M., and Alhaddad, H. 2012. Salivary enzymes are injected into xylem by the glassy-winged sharpshooter, a vector of Xylella fastidiosa. J. Insect Physiol. 58:949-959.

7. Backus, E. A., Holmes, W. J., Schreiber, F., Reardon, B. J., and Walker, G. P. 2009. Sharpshooter X wave: Correlation of an electrical penetration graph waveform with xylem penetration supports a hypothesized mechanism for Xylella fastidiosa inoculation. Ann. Entomol. Soc. Am. 102: 847-867.

8. Backus, E. A., and McLean, D. L. 1982. The sensory systems and feeding behavior of leafhoppers. I. The aster leafhopper, Macrosteles fascifrons Stål (Homoptera: Cicadellidae). J. Morphol. 172:361-379.

9. Backus, E. A., and Morgan, D. J. W. 2011. Spatiotemporal colonization of Xylella fastidiosa in its vector supports the role of egestion in the inoculation mechanism of foregut-borne plant pathogens. Phytopathology 101:912-922.

10. Blackman, R. L. 1976. Biological approaches to the control of aphids. Philos. Trans. Roy. Soc. London, B 274:473-488.

11. Bradley, R. H. E. 1964. Aphid transmission of stylet-borne viruses. Pages 148-174 in: Plant Virology. M. K. Corbett, and H. D. Sisler, eds. University of Florida Press, Gainsville, FL.

12. Bradley, R. H. E., and Ganong, R. Y. 1955. Evidence that potato virus Y is carried near the tip of the stylets of the aphid vector Myzus persicae. Can. J. Microbiol. 1:775-782.

13. Bradley, R. H. E., and Ganong, R. Y. 1955. Some effects of formaldehyde on potato virus $\mathrm{Y}$ in vitro, and ability of aphids to transmit the virus when their stylets are treated with formaldehyde. Can. J. Microbiol. 1:783-793.

14. Chatterjee, S., Almeida, R. P. P., and Lindow, S. 2008. Living in two worlds: The plant and insect lifestyles of Xylella fastidiosa. Annu. Rev. Phytopathol. 46:243-271.

15. Chen, J., Groves, R., Civerolo, E. L., Freeman, M., and Zheng, Y. 2005. Two Xylella fastidiosa genotypes associated with almond leaf scorch disease on the same location in California. Phytopathology 95:708-714.

16. Davis, M. J., French, W. J., and Schaad, N. W. 1981. Axenic culture of the bacteria associated with phony disease of peach and plum leaf scald. Curr. Microbiol. 6:309-314.

17. Day, M. F., and Irzykiewicz, H. 1954. On the mechanism of transmission of non-persistent phytopathogenic viruses by aphids. Aust. J. Biol. Sci. 7: 251-273.

18. Fereres, A., and Collar, J. L. 2001. Analysis of noncirculative transmission by electrical penetration graphs. Pages 87-109. in: Virus-Insect-Plant Interactions. K. F. Harris, O. P. Smith, and J. E. Duffus, eds. Academic Press, New York. 
19. Foil, L. D., Seger, C. L., French, D. D., Issel, C. J., McManus, J. M., Ohrberg, C. L., and Ramsey, R. T. 1988. Mechanical transmission of bovine leukemia virus by horse flies (Diptera: Tabanidae). J. Med. Entomol. 25:374-376.

20. Forbes, A. R. 1977. The mouthparts and feeding mechanism of aphids. Pages 83-103 in: Aphids as Virus Vectors. K. F. Harris and K. Maramorosch, eds. Academic Press, New York.

21. Francis, M., Lin, H., Cabrera-LaRosa, H., Doddapaneni, H., and Civerolo, E. L. 2006. Genome-based PCR primers for specific and sensitive detection and quantification of Xylella fastidiosa. Eur. J. Plant Pathol. 115:203-213.

22. Goodchild, A. J. P. 1966. Evolution of the alimentary canal in the Hemiptera. Biol. Rev. 41:97-140.

23. Habibi, J., Backus, E. A., and Czapla, T. H. 1993. Plant lectins affect survival of the potato leafhopper (Homoptera: Cicadellidae). J. Econ. Entomol. 86:945-951.

24. Harris, K. F. 1977. An ingestion-egestion hypothesis of noncirculative virus transmission. Pages 165-220 in: Aphids as Virus Vectors. K. F. Harris and K. Maramorosch, eds. Academic Press, New York.

25. Harris, K. F., and Bath, J. E. 1973. Regurgitation by Myzus persicae during membrane feeding: Its likely function in transmission of plant viruses by vectors. Ann. Entomol. Soc. Am. 66:793-796.

26. Harris, K. F., and Harris, L. J. 2001. Ingestion-egestion theory of cuticulaborne virus transmission. Pages 111-132 in: Virus-Insect-Plant Interactions. K. F. Harris, O. P. Smith, and J. E. Duffus, eds. Academic Press, New York.

27. Hill, B. L., and Purcell, A. H. 1995. Acquisition and retention of Xylella fastidiosa by an efficient vector, Graphocephala atropunctata. Phytopathology 85:209-212.

28. Killiny, N., and Almeida, R. P. P. 2009. Xylella fastidiosa afimbrial adhesins mediate cell transmission to plants by leafhopper vectors. Appl. Environ. Microbiol. 75:521-528.

29. Killiny, N., and Almeida, R. P. P. 2009. Host structural carbohydrate induces vector transmission of a bacterial plant pathogen. Proc. Natl. Acad. Sci. USA 106:22416-22420.

30. Killiny, N., and Almeida, R. P. P. 2014. Factors affecting the initial adhesion and retention of the plant pathogen Xylella fastidiosa in the foregut of an insect vector. Appl. Environ. Microbiol. 80:420-426.

31. Killiny, N., Hernandez Martinez, R., Korsi Dumenyo, C., Cooksey, D. A., and Almeida, R. P. P. 2013. The exopolysaccharide of Xylella fastidiosa is essential for biofilm formation, plant virulence, and vector transmission. Mol. Plant-Microbe Interact. 26:1044-1053.

32. Kloft, W. J. 1977. Radioisotopes in aphid research. Pages 291-310 in: Aphids as Virus Vectors. K. F. Harris and K. Maramorosch, eds. Academic Press, New York.

33. Krugner, R., Sisterson, M. S., and Lin, H. 2012. Effects of gender, origin, and age on transmission of Xylella fastidiosa to grapevines by Homalodisca vitripennis (Hemiptera: Cicadellidae). Ann. Entomol. Soc. Am. 105:280-286.

34. Ledbetter, C. A., and Rogers, E. E. 2009. Differential susceptibility of Prunus germplasm (subgenus Amygdalus) to a California isolate of Xylella fastidiosa. HortScience 44:1928-1931.

35. Leopold, R. A., Freeman, T. P., Buckner, J. S., and Nelson, D. R. 2003. Mouthpart morphology and stylet penetration of host plants by the glassywinged sharpshooter, Homalodisca coagulata (Homoptera: Cicadellidae). Arthropod Struct. Dev. 32:189-199.

36. Martin, B., Collar, J. L., Tjallingii, W. F., and Fereres, A. 1997. Intracellular ingestion and salivation by aphids may cause the acquisition and inoculation of non-persistently transmitted plant viruses. J. Gen. Virol. 78:2701-2705.

37. McLean, D. L., and Kinsey, M. G. 1964. A technique for electronically recording aphid feeding and salivation. Nature 202:1358-1359.

38. Miles, P. W. 1972. The saliva of Hemiptera. Adv. Insect Physiol. 9: 183-255.

39. Miles, P. W. 1999. Aphid saliva. Biol. Rev. Camb. Philos. Soc. 74:41-85.

40. Moreno, A., Garzo, E., Fernandez-Mata, G., Kassem, M., Aranda, M. A., and Fereres, A. 2011. Aphids secrete watery saliva into plant tissues from the onset of stylet penetration. Entomol. Exp. Appl. 139:145-153.

41. Morgan, J. K., Luzio, G. A., Ammar, E. D., Hunter, W. B., Hall, D. G., and Shatters, R. G., Jr. 2013. Formation of stylet sheaths in āere (in air) from eight species of phytophagous hemipterans from six families (Suborders: Auchenorrhyncha and Sternorrhyncha). PLoS One 8:11.

42. Nault, L. R. 1997. Arthropod transmission of plant viruses: A new synthesis. Ann. Entomol. Soc. Am. 90:521-541.

43. Nault, L. R., Hunt, R. E., and Ammar, E. D. 1988. Specificity in transmission of leafhopper-borne maize chlorotic dwarf virus. Pages 463-471 in: Proceedings of the 6th Auchenorrhyncha Meeting. C. Vidano and A. Arzone, eds. Consiglio Nazionale delle Ricerche, Italy, Special Project IPRA, Turin.

44. Newman, K. L., Almeida, R. P. P., Purcell, A. H., and Lindow, S. E. 2003. Use of a green fluorescent strain for analysis of Xylella fastidiosa colonization of Vitis vinifera. Appl. Environ. Microbiol. 69:7319-7327.

45. Powell, G. 1991. Cell membrane punctures during epidermal penetrations by aphids: Consequences for the transmission of two potyviruses. Ann. Appl. Biol. 119:313-321.

46. Powell, G., Pirone, T., and Hardie, J. 1995. Aphid stylet activities during potyvirus acquisition from plants and an in vitro system that correlates with subsequent transmission. Eur. J. Plant Pathol. 101:411-420.

47. Purcell, A. H., and Finlay, A. 1979. Evidence for noncirculative transmission of Pierce's disease bacterium by sharpshooter leafhoppers. Phytopathology 69:393-395.

48. Purcell, A. H., Finlay, A. H., and McLean, D. L. 1979. Pierce's disease bacterium: Mechanism of transmission by leafhopper vectors. Science 206:839-841.

49. Rogers, E. E., and Backus, E. A. 2014. Anterior foregut microbiota of the glassy-winged sharpshooter explored using deep 16S rRNA gene sequencing from individual insects. PLoS One 9:e106215.

50. Roper, M. C., Greve, C. L., Labavitch, J. M., and Kirkpatrick, B. C. 2007. Detection and visualization of an exopolysaccharide produced by Xylella fastidiosa in vitro and in planta. Appl. Environ. Microbiol. 73:7252-7258.

51. Tjallingii, W. F. 1978. Electronic recording of penetration behaviour by aphids. Entomol. Exp. Appl. 24:721-730.

52. Tjallingii, W. F. 1985. Membrane potentials as an indication for plant cell penetration by aphid stylets. Entomol. Exp. Appl. 38:187-193.

53. Tjallingii, W. F. 2006. Salivary secretions by aphids interacting with proteins of phloem wound responses. J. Exp. Bot. 57:739-745.

54. Uzest, M., Gargani, D., Dombrovsky, A., Cazevieille, C., Cot, D., and Blanc, S. 2010. The "acrostyle": A newly described anatomical structure in aphid stylets. Arthropod Struct. Dev. 39:221-229.

55. Uzest, M., Gargani, D., Drucker, M., Hebrard, E., Garzo, E., Cadresse, T., Fereres, A., and Blanc, S. 2007. A protein key to plant virus transmission at the tip of the insect vector stylet. Proc. Natl. Acad. Sci. USA 104:17959-17964.

56. Watson, M. A., and Plumb, R. T. 1972. Transmission of plant-pathogenic viruses by aphids. Annu. Rev. Entomol. 17:425-452. 